DOI: 10.15393/j9.art.2012.337

\begin{abstract}
Вячеслав Анатольевич Кошелев
доктор филологических наук, профессор, заведуюший кафедрой русской классической литературь, Новгородский государственный университет им. Ярослава Мудрого (Великий Новгород, Российская Федерация) anatoly.koshelev@novsu.ru
\end{abstract}

\title{
«ДЕНЬ БОРОДИНА» И ЧЕТИИ МИНЕИ
}

Аннотация: Лирическая повесть «Наташа» - первое опубликованное оригинальное произведение П. А. Катенина. Из всех произведений поэта оно имело самый большой успех у читателей и критиков. Традиционно «Наташу» Катенина исследователи рассматривают как балладу, а ее источником считают немецкую балладу Г. А. Бюргера «Ленора». В данной статье устанавливается наиболее очевидный источник лирической повести Катенина. Автор доказывает, что им является «Страдание святых мучеников Адриана и Наталии» из известных Четий Миней Св. Димитрия Ростовского. Оно помещено под 26 августа - днем Бородинского сражения. Установление житийного источника позволяет уточнить многочисленные аспекты содержания текста. Лирическая повесть Катенина стоит у истоков «Наташиного текста» русской литературы: символ рождения («Наталья» - от лат. «К рождению относящаяся) одновременно осознается и как «смертный» («день Бородина» - жесточайшего сражения 19 века). Катенин вводит представление о смерти как о возможности счастливого будущего - его героиня Наташа умирает, чтобы остаться жить с возлюбленным. С произведения Катенина появляется новый тип поэтического выражения патриотического сознания: «Наташа» оказалась первым «военным» произведением русской литературы, в котором воспевалась не война, а мирная жизнь обыкновенных людей.

Ключевые слова: источник, баллада, жития святых, «Наташин текст», новый тип патриотического сознания

$\Lambda$

ирическая повесть П. А. Катенина «Наташа» впервые была напечатана в июльской книжке «Сына Отечества» на 1815 г. Первая публикация сопровождалась редакционным примечанием:

Издатели благодарят именем читателей своих за доставление им сей пьесы ${ }^{1}$.

Такое примечание могло означать то, что текст «сей пьесы» был передан в редакцию не самим автором, а кем-то другим. Действительно, это произведение (написанное еще в 1814 г., когда Катенин был в заграничном походе) было еще до публикации весьма популярно. По свидетельству критика «Вестника Европы», «Наташа» «имела успех более других» произведений Катенина:

Мне случалось видеть ее во многих альбомах ${ }^{2}$.

При этом «Наташа» стала, в сущности, первым опубликованным оригинальным стихотворением Павла Катенина, который еще в предвоенные годы зарекомендовал себя как поэт «с большим дарованием» (К. Н. Батюшков) $)^{3}$ - в «Цветнике» 1810 г. появлялись его переводы и подражания Оссиану, Геснеру, Вергилию, Биону. Он уже, по выражению Пушкина, «воскресил Корнеля гений величавый» (3 февраля 1811 г. в Петербурге была представлена трагедия 
Корнеля «Ариана» в его переводе). Он пользовался славой вполне самобытного и «капризного» литературного деятеля, восставшего против перифрастического стиля и «интимности» самовыражения «карамзинистов»...

Традиционно катенинскую «Наташу» рассматривают как балладу: она даже включена в «антологию баллады» ${ }^{4}$ При этом ее сюжет возводят к известной балладе Г. А. Бюргера «Ленора», и получается, что немецкая баллада стала основой сюжета пяти самостоятельных (и получивших огромную популярность) русских произведений. Тот же Катенин, помимо «Наташи», написал еще «Ольгу» (1816 г. - с подзаголовком «Из Бюргера»). А Жуковский, как известно, обработал этот же сюжет еще раньше Катенина: в «Людмиле» (1808) и в знаменитой «Светлане» (1813). Да к тому же «наверхосытку» еще и представил точный перевод этой самой «Леноры» (1831).

А. И. Журавлева рассмотрела «Наташу» Катенина как своеобразную vice versa «Светланы» Жуковского. «Исходная» баллада Бюргера, пишет она, «представляет, внешне по крайней мере, назидательную историю: не роптала бы, не была бы наказана. Но русская литература эту жесткую мораль не приняла. Жуковский создает свою “Светлану” в стремлении преодолеть неумолимо и, в сущности, несправедливо свирепую ситуацию “Людмилы”. "Наташа” Катенина - тоже попытка создать свою “Анти-Ленору”, и очень удачная. В творчестве Катенина она занимает такое же место, что "Светлана" у Жуковского. В противоположность Жуковскому, совсем отказавшемуся в “Светлане" от всякой войны и тем утешившего современников, Катенин, наоборот, переносит действие именно в войну 1812 года... У Жуковского - встреча влюбленных, у Катенина “...как сидела, как спала, К жизни с милым умерла”» [2, 95-96].

Но если относить первое оригинальное создание Катенина к жанру баллады, то нельзя не заметить, что здесь «не хватает» основных составляющих баллады, которая есть «стихотворная повесть о чудесном» $[4,191]$ (ср. в «Светлане» Жуковского: «В ней большие чудеса»), которая предполагает и «момент легенды», и «мрачный колорит» ${ }^{5}$. Да и сама героиня как-то уж очень не похожа на балладную «деву»:

Ах! жила была Наташа,
Свет Наташа красота...
…...............................
Где уста, как мед душистый,
Бела грудь, как снег пушистый,
Рдяны щеки, маков цвет?..

Сюжет поэтического повествования Катенина предельно прост и даже наивен. На фоне романтико-патриотической поэзии времени наполеоновских войн он поражает своей безыскусственностью и полным отсутствием не только громких слов и патриотических ти- 
рад, но даже и красивых «подвигов» людей, которые живут «любовью к родине дыша» (К. Ф. Рылеев). Катенинские герои действительно так живут - но не говорят об этом.

Наташа, кажется, живет только «тихой» любовью к своему «милому другу»: «Длися, длися, дорогое / Время краткое, златое!..» А о внезапном несчастии сообщается попросту:

Вдруг поднялся враг войною
Русь заграбить и зажечь;
Всюду льется кровь рекою,
Всюду блещет огнь и меч.
Нивы стоптанны пропали,
Грады, веси запылали...

Наступают «грусть» и «тоска», и Наташа сама направляет «милого друга» в бой, мотивируя эту необходимость тоже очень простым аргументом: «Не сражаться за отчизну, / Одному отстать от всех - / В русских людях стыд и грех».

«Милый друг», у кого давно «кипит ретивое», «рад, что мысли в нас одне», и отправляется воевать, обещая: «Верь, хоть мертвый, хоть живой, / Не расстанусь я с тобой». Битва за «родную Москву» происходит в день Наташиных именин:

Именинница Наташа!

В день твой, в день Бородина,

За здоровье друга чаша

Налита тобой вина.

И о нем пируют гости;

А его в тот час уж кости

На ближайшем там селе

Преданы сырой земле...

Никаких особенных героических подвигов милый Наташи не совершил - просто погиб в решающей битве. «Известье злое» Наташа восприняла тяжело: «Не пила три дни, не ела, / Как больная исхудела; / Нет покоя ей, ни сна, / И как мертвая бледна». Измученная, сидя «у стенки», героиня забылась «усталым, слабым сном», и тут ее мертвый возлюбленный «стал пред ней как бы живой»:

Будит: «Встань, проснись, Наташа!

Ждет давно нас свадьба наша;

Под венец скорей пойдем,

Вместе век свой заживем...»

В отличие от балладной ситуации, в этом явлении мертвого возлюбленного нет ни мистического, ни мрачного колорита: «милый друг» выполняет свое обещание, предлагая "райский покой» и продолжение жизни «вместе» пусть и в ином мире. Никакой «магии»: все совершается после заупокойной молитвы «пред иконою 
святой». И финал этой истории такой же простой и будничный, грустный - но не трагический:
Тут Наташа помолилась,
Тут во сне перекрестилась:
Как сидела, как спала,
К жизни с милым умерла.

Просто - продолжилась прерванная было «жизнь с милым».

Наиболее очевидным источником этой лирической повести была не баллада Гердера и не «Людмила» Жуковского, а житие святой мучениць Наталии, вошедшее в четвертую книгу Четьих Миней, составленную Св. Димитрием Ростовским. Эта книга, любимое чтение благочестивых людей, была в России очень распространена: вышедшая в 1705 г., она на протяжении XVIII столетия переиздавалась более 10 раз. Под 26 августа помещено обширное «Страдание святых мучеников Адриана и Наталии».

Основным героем этого жития является Адриан, молодой (28 лет) человек, бывший уважаемым судьей в Никомидии, которую захватил нечестивый царь Максимиан. Преисполнившись сочувствия к христианам мученикам и уверовав в хвалимого ими Бога, Адриан объявил себя христианином, за что, по приказу царя, был посажен в темницу и подвергнут мучениям. Его молодая жена («были соединены супружеством только один год») Наталия, прекрасная и богатая женщина, сама была тайною христианкой - и не переставала укреплять мужа в стойкости как поступками, так и речами:

Теперь без печали пойдешь ты в будущую жизнь и найдешь такое сокровище, которого не получат там те, которые собирают себе большое богатство и приобретают имения. Там уже не будет им времени на то, чтобы приобретать что-либо, или давать взаймы, или самим от кого занять, когда никто не может избавить от вечной смерти во аде и от мук геенских; там никто не поможет друг другу - ни отец сыну, ни мать дочери, ни великое земное богатство собравшему его, ни рабы - господину своему, но каждый понесет свое наказание. Твои же все добродетели, господин мой, пойдут с тобою ко Христу, чтобы воспринять тебе от Него блаженство, уготованное любящим Его.

Основным «мучеником» в повествовании явился Адриан Наталия проходит на втором плане. После гибели мужа она взяла себе руку Адриана и хранила в своем доме. Царский тысяченачальник хотел жениться на красивой и богатой вдове, но она, узнав это, скрылась в Византию. И финал жития прямо напоминает сюжет и характер стихотворения Катенина:

Придя в храм к телам святых мучеников, святая Наталия с несказанною радостью припала к ним, лобызая их и проливая от радости слезы; приложив руку святого Адриана к его телу, она преклонила колена и долго молилась. Потом после продолжительной молитвы она встала и облобызала находящихся на оном месте братьев и сестер, так как там собралось много верных христиан, 
которые приняли ее с радостью, ввели ее внутрь дома и стали просить ее немного отдохнуть, так как видели, что она очень изнемогла от морского плавания. Когда она крепко заснула, ей явился во сне святой Адриан и сказал ей: «Хорошо, что ты пришла сюда, раба Христова и дочь мученическая: приди в покой свой, уготованный тебе от Господа, приди и восприми должную тебе награду!» Встав от сна, святая Наталия рассказала свой сон находившимся при ней христианам и просила их помолиться о ней. После этого она уснула снова. Верующие чрез час пришли разбудить ее, но нашли ее уже скончавшеюся, ибо ее святая душа отошла в вечный покой ко Господу‥

В католической традиции основным «мучеником» из этой пары почитается Адриан: в Риме, в церкви его имени, покоятся его мощи. В русской православной традиции особенно почитается именно Наталия. Ей посвящено служебное песнопение:

Мученицы Твои, Господи, во страданиях своих венцы прияша нетленныя от Тебе Бога нашего: имуще бо крепость Твою мучителей низложиша, сокрушиша и демонов немощныя дерзости, тех молитвами спаси души наша» (Тропарь, глас 4).

И с ее именем издавна оказался связан день 26 августа (по старому стилю) - этот день стал «великим днем Бородина».

Русское имя Наталья происходит от латинского natalis и означает «к рождению относящаяся, природная». Возник своеобразный парадокс «натальина дня»: символ рождения и жизнеутверждения, он одновременно осознается и как «смертный» - и в этом смысле особо памятный - день жесточайшего сражения XIX столетия. Впервые этот культурный парадокс был заявлен именно в «Наташе» Катенина: «чаша вина» поднимается «за здоровье друга», «а его в тот час уж кости» в это время предаются погребению...

Именно эта лирическая повесть Катенина стала у истоков «Наташиного текста» русской литературы - таковой можно выделить по аналогии с «Лизиным текстом» русской литературы, возникшим после «Бедной Лизы» Н. М. Карамзина [5], [6]. Наиболее ярко этот «Наташин текст» проявился у Пушкина, жена которого, рожденная на другой день после Бородинской битвы, получила именно это имя (которое, впрочем, было весьма часто использовано Пушкиным при именовании своих персонажей) [3], [1, 145-150]. Современный исследователь констатирует: «ННаталья» и «Бородино» - две сквозные линии, пересекающие пространство пушкинского мира» [3, 22].

Однако важнее для нашей темы оказывается не рождение «Наташиного текста», а появление - с этим стихотворением и его источником - нового типа поэтического выражения патриотического сознания. Традиционные образчики стихотворной беллетристики интересующего нас локального периода собраны в показательном сборнике «Собрание стихотворений, относящихся к незабвенному 1812 году», вышедшем в Москве в 1814 г. Стихотворение Катенина в него не вошло: оно было опубликовано чуть позднее. Не во- 
шли и многочисленные «гусарские» стихи Дениса Давыдова: при своем появлении они имели статус «незаконных» и неудобных в печати текстов и были рассчитаны на устное бытование.

Тех стихотворных текстов, по которым потомки восстанавливали «поэтическое одушевление» «незабвенного 1812 года», современники попросту не заметили, представив в двух томах этого «Собрания...» более 150 текстов, отражающих весь жанровый репертуар патриотической поэзии начала XIX в.

«Собрание...» открывается огромным патриотическим манифестом наиболее именитого из русских пиитов Г. Р. Державина под заглавием «Гимн лироэпический на прогнание французов из отечества 1812 года, во славу всемогущего Бога, великого Государя, верного народа, мудрого вождя и храброго воинства Российского». В этом огромном «гимне», помимо славословий в адрес «вождя победителей» и проклятий в адрес «нечестивых завоевателей», содержалось множество нелепостей (вплоть до арифметических подсчетов «числа зверя», заключенного в имени Наполеона Бонапарта). Читанный в «Беседе любителей русского слова», этот «гимн» сразу же стал объектом показательных пародий (например, лицеиста Пушкина в сатире «Тень Фон-Визина» ${ }^{8}$ ). А К. Н. Батюшков высмеял жанровые составляющие тогдашних поэтических восхвалений подзаголовком своей сатиры «Певец, или Певцы в Беседе Славенороссов»: «Балладо-эпико-лиро-комико-эпизодический гимн» ${ }^{9}$.

За гимном следовали оды - наиболее частый жанр в стихотворной беллетристике этого периода: «Ода на истребление врагов и изгнание их из пределов любезного Отечества» (П. Г. Кутузов), «Ода на случай войны с французами 1812 года» (М. Невзоров). «Неумирающая» ода сочинялась по самым разным поводам: «Ода на освобождение Москвы» (Д. И. Хвостов), «Ода на бегство Наполеона от Малоярославца, через Можайск, Гжатск и Вязьму, беспрерывными поражениями его армии сопровождаемое» (И. П. Кованько), «Ода на парение Орла над российскими войсками при селе Бородине в августе 1812» (К. 3-кий), «Ода на новый 1813-й год» (М. Виноградов) и т. д. и т. п.

Жанр «Певца во стане русских воинов» Жуковского Б. М. Эйхенбаум определил как «рапсодию», выполнявшую агитационный заказ:

В основе этого большого стихотворения лежит распространенный в ту эпоху жанр «застольной песни», образцы которого имеются и в немецкой военной и студенческой лирике. Этот жанр развернут привычным для Жуковского балладным материалом. <...> Агитационная задача облегчала этот эксперимент, освобождая от забот о сюжете, о герое и естественно организуя все движение на основе единой «застольной» интонации. «Певец» - вещь эклектическая и компромиссная [7, 32]. 
Поэтому, кстати, в том же «Собрании...» представлены многочисленные подражания: «Певец среди московских граждан 11 октября 1813 года» (И. Попов), «Певец на гробах братьев воинов россиян» и т. д.

Стихи, представленные в «Собрании...», весьма однообразны. Много «духовных» песнопений, обращений к Богу или подражаний псалмам: «Песнь Богу, покровителю России» (Н. Волков), «Моя молитва» (Н. Остолопов), «На совершенное истребление неприятельских войск в пределах России (Подражание 78 псалму)» (А. Писарев), «Москва, оплакивающая бедствия свои, нанесенные ей в 1812 году рукою жестокого и злочестивого врага, и вместе утешающая страждущих сынов своих» (священник Матфей Аврамов) и т. д. «Стихи похвальные» конкретным героям войны: «Стихи генералу Раевскому» (С. Н. Глинка), «Стихи графу Витгенштейну на одержание им над французами победы» (А. Волков), «Стихи на подвиги двух смоленских помещиков, Энгельгардта и Шубина, и на монаршие щедроты, излиянные на них» (А. Писарев). Множество эпитафий на кончину Кутузова и Багратиона. Еще больше «надписей к портретам» разных военачальников...

В военную годину расцвел жанр «солдатской песни», исполненной лихих призывов к русскому воинству и долженствующей «ободрить дух народа в беде». Это - целая серия рифмованных «ростопчинских афишек», образцы «лубочного» стихотворства: «Солдатская песня» (И. Кованько; под тем же заглавием Н. Ильин, Ф. Глинка), «Песнь к русским воинам, написанная отставным из Фанагорийского гренадерского полку солдатом Николаем Остафьевым июля...дня 1812 года», «Авангардная песня» (Ф. Глинка), «Песня богатырям русским» (В. Колосов), «Хор на новый 1813 год» (Н. Николев), «Солдатская песня в память князя Кутузова Смоленского», «Песня русских поселян русским воинам» (С. Глинка), «Песнь Донскому воинству» (Н. Шатров), «Песня ратников Санкт-Петербургского ополчения» (М. Шуленников) и т. д.

В том же лубочном, агитационно-пропагандистском духе писались и сатиры: «Побег Наполеона Карловича из земли Русской», «Исповедь Наполеона французам» (Н. Николев), «Наполеонов бостон» (Я. Пожарский), «Совет Русского французам», «Завещание Наполеона Бонапарте» и т. п.

Только два текста в обширном «Собрании...» обозначены как написанные женщинами: «На кончину графа Ал. Ив. Кутайсова, в Бородинском сражении убитого 1812 года августа 26» (А. П. Бунина) и «Стансы» (за подписью «Московитянка»). По тональности эти «сетования русской девы» по убитым воинам оказываются наиболее близки интересующей нас лирической повести Катенина. 
Впрочем, есть одно существенное различие. Под заглавием «Сетования русской девы» печатался, например, посвященный той же ситуации романс Ф. Н. Глинки (1818). Там тоже воспроизводился «плач» русской женщины, потерявшей своего «любезного»: «Он давно за Рейном шумным / Беспробудным сном почил!» Но Глинка завершает эти «сетования» оптимистическим и патриотическим финальным призывом воину:

О тебе дойдет лишь слава

В милый сердцу русский край, Что на битвах ты, как русский, Храбр и страшен был врагам.

Много пало, много пало

Там, в зареинских полях;

Но блажен, кто умер славно:

Он бессмертен будет век!.. ${ }^{10}$

А про вечное «бессмертие» неназванного «милого друга» Наташи - ничего не говорится... Более того: само собою предполагается «незнаменитая», «неславная» гибель - после нее «милый друг» не будет интересен никому, кроме возлюбленной. В памяти людей он не останется. Единственное упование - Бог и Наташа. Оно выражается в последних «призывных» словах «мертвого возлюбленного»:

Нашу призрел Бог разлуку,

Веру райский ждет покой;

Жениху дай, радость, руку,

Помолись, и в путь за мной.

И если «русская дева» Федора Глинки остается жить - и «вечно» помнить о своем любезном, то катенинская Наташа парадоксальным образом умирает, чтобы остаться жить с возлюбленным: «К жизни с мильм умерла». В отличие от «балладного» представления о смерти как наказании, Катенин вводит представление о смерти как о возможности счастливого будущего. Альтернативу: «жизнь без милого» - «смерть с милым» героиня решает в пользу смерти.

При этом сам источник лирической повести - христианское житие - освобождается от излишне «божественных» предпочтений. Житийный «милый друг» Наталии приглашал любимую прийти «в покой свой, уготованный тебе от Господа» и принять его как «должную награду». Мертвый «милый друг» Наташи в стихотворении Катенина просто делает ей формальное предложение: «Ждет давно нас свадьба наша; / Под венеи, скорей пойдем...» Никакого «покоя», даруемого в награду за «мучения», - исключительно упование на скорое возвращение долгожданного счастья, которое, как раньше, будет «длиться, длиться, дорогое»... 
Начавшаяся война - не «желанное» или «жданное» событие (каковым она казалась, например, лирическому герою Д. Давыдова). Это - трагическая помеха «длящемуся» счастью. И идут на нее только в силу традиции: нельзя же «одному отстать от всех». И не предвкушают никаких «высоких» подвигов - просто в безвестности гибнут в генеральном сражении, странным образом связавшемся с «женскими» именинами...

В сущности, «Наташа» оказалась первым «военным» произведением русской словесности, в котором, по закону парадокса, воспевалась не война, а - тихая и простая мирная жизнь обыкновенных людей. «Стихи о Наташе, — писал современный рецензент, - нравятся мне простотою и легкостью: ничего нет принужденного, ничего натянутого» ${ }^{11}$.

Именно это - редкое для тогдашней литературной традиции качество стихотворения Катенина восходит к его очевидному, но «незамеченному» православному источнику.

\section{Примечания}

1 Сын Отечества. 1815. № 13. С. 16.

2 Вестник Европы. 1823. № 1. С. 197.

3 Из письма К. Н. Батюшкова к Н. И. Гнедичу от 6 сентября 1809 // Батюшков К. Н. Соч.: В 2 т. М., 1989. Т. 2. С. 101.

4 Эолова арфа: Антология баллады / Сост., предисл. и коммент. А. А. Гугнина. М., 1989. С. 414-416.

5 Краткая литературная энциклопедия. М., 1962. Т. 1. С. 422.

6 Катенин П. А. Избранные произведения. М.; Л., 1965. С. 79-82. Далее цитируется по этому тексту.

7 Минеи-Четии Св. Димитрия Ростовского. СПб., 1891. Ч. 4. С. 491-524.

8 Пушкин А. С. Лицейские стихотворения. 1813-1817. СПб., 1999. С. 227, 631.

9 Батюшков К. Н. Соч.: В 2 т. М., 1989. Т. 1. С. 388.

10 Глинка Ф. Н. Избранные произведения. Л., 1957. С. 128-129.

11 Вестник Европы. 1823. № 1. С. 197.

\section{Список литературы}

1. Букалов А. М. Пушкинская Африка: По следам «Романа о царском арапе». СПб.: Алетейя, 2006. 320 с.

2. Журавлева А. И. «Песнь о вещем Олеге» А. С. Пушкина // Пушкин и его современники. Псков, 1970. С. 90-100.

3. Илюшин A. A. «Бородинское имя» жены А. С. Пушкина // Война 1812 года и русская литература. Исследования и мат-лы. Тверь, 1993. С. 20-31.

4. Томашевский Б. В. Теория литературы. Поэтика. М.; Л.: Госиздат, 1930. 240 с.

5. Топоров В. Н. «Бедная Лиза» Карамзина: Опыт прочтения. М.: РГГУ, 1995. 512 с.

6. Топоров В. Н. Рассказ Л. Добычина «Встречи с Лиз» в контексте «бедной Лизы» «железного века» // «Вторая проза»: Русская проза 20-30-х годов ХХ века. Trento, 1995. C. 77-112.

7. Эйхенбаум Б. М. От военной оды к «гусарской песне» // Давыдов Д. Полное собрание стихотворений. Л.: Изд-во Писателей в Ленинграде, 1933. С. 51-68. 


\title{
Vyacheslav Anatol'evich Koshelev \\ Doctor of Philology, Head of the Department of Russian Classical Literature, Yaroslav-the-Wise Novgorod State University (Veliky Novgorod, Russian Federation) anatoly.koshelev@novsu.ru
}

\section{“THE DAY OF BORODINO" AND THE MENAION}

\begin{abstract}
Natasha was P. A. Katenin's first work to be published, famous for its lyricism which made it the author's greatest success with both critics and readers. Traditionally Natasha was classified as a ballad, with G. A. Burger's Lenora named as its source. We claim to have discovered a more obvious source of this text - The Martyrdom of Sts. Adrian and Natalia in St. Dimitry of Rostov's version of the Menaion. It was included in the Menaion entry for August 26 - the day of the Battle of Borodino. This hagiographic source sheds light on numerous episodes in Katenin's lyrical tale - a text which started the "Natalia text" tradition in Russian literature. The symbol of birth (the name Natalia is derived from the Latin word for birth) is thus linked to death (via the day of one of the bloodiest battles of the $19^{\text {th }}$ century). Katenin introduces the idea of death as a chance for a happy future, as his protagonist dies to keep on living with her beloved. Katenin's tale opens the new type of poetic expression of patriotic consciousness. Natasha was the first war text in Russian literature to glorify peaceful life of common people, rather than war.

Keywords: source, ballad, biography of saint, "Natalia text", new type of patriotic consciousness
\end{abstract}

\section{References}

1. Bukalov A. M. Pushkinskaya Afrika: Po sledam «Romana o tsarskom arape» [Alexander Pushkin's Africa: On the Trail of the Novel "Peter the Great's Negro"]. Saint-Petersburg, Aleteyya Publ., 2006. 320 p.

2. Zhuravleva A. I. «Pesn' o veshchem Olege» A. S. Pushkina ["The Song of Wise Oleg” by A. S. Pushkin]. Pushkin i ego sovremenniki [Pushkin and his Contemporaries]. Pskov, 1970, pp. 90-100.

3. Ilyushin A. A. "Borodinskoe imya» zheny A. S. Pushkina [Borodino's Name of Pushkin's Wife]. Voyna 1812 goda i russkaya literatura. Issledovaniya i materialy [The War of 1812 and Russian Literature. Studies and Materials]. Tver, 1993, pp. 20-31.

4. Tomashevskiy B. V. Teoriya literatury. Poetika [Theory of Literature. Poetics]. Moscow; Leningrad, Gosudarstvennoe izdatel'stvo, 1930. 240 p.

5. Toporov V. N. "Bednaya Liza» Karamzina: Opyt prochteniya ["Poor Liza" by Nikolai Karamzin: An Attempted Interpretation]. Moscow, The Russian State University for the Humanities Publ., 1995. 512 p.

6. Toporov V. N. Rasskaz L. Dobychina «Vstrechi s Liz» v kontekste «bednoy Lizy» «zheleznogo veka» ["The Meetings with Liz" by Leonid Dobychin in the Context of "Poor Liza" of the "Iron Age"]. «Vtoraya proza»: Russkaya proza 20-30-kh godov XX veka ["The Second Prose": Russian Prose in the 20-30s of the 20th Century]. Trento, 1995, pp. 77-112.

7. Eykhenbaum B. M. Ot voennoy ody k «gusarskoy pesne» [From Military Ode to "Hussar's Song"]. Davydov D. Polnoe sobranie stikhotvoreniy [The Complete Poems by Denis Davydov]. Leningrad, Izdatel'stvo Pisateley v Leningrade, 1933, pp. 51-68. 